\title{
Annotation
}

\section{Breast Milk and Defence Against Infection in the Newborn}

In industrialized countries newborn infants are being exposed to an increasingly artificial environment, with larger delivery units, an increased use of disinfectants and antibiotics, and a decreased incidence of breast feeding. The fact that this trend has continued side by side with a situation where infections have played a diminishing role in neonatal morbidity and mortality has created the impression that such changes have been beneficial, or at least not harmful, to the infant.

Lately some reports have suggested a changing pattern with an increased frequency of colonization and infection caused by Gram-negative bacteria (McCracken and Shinefield, 1966; Samuel and Gould, 1967; Conn, 1969; British Medical Journal, 1970). There may be a multifactorial background to such an increase, including some of the factors listed above. The possible role of the low consumption of breast milk has attracted little attention, and historically the fact that the antibodies of milk are not absorbed from the gut in the human (Vahlquist, 1958) is perhaps partly responsible for this. With the appreciation of secretory IgA as the main immunoglobulin in breast milk, and also as an important immune factor for epithelial surfaces, a new situation has developed. This, as well as the recognition of several other antibacterial factors in breast milk, has reopened discussion of the value of breast milk.

Bacterial Colonization of the Alimentary Tract of the Newborn in Relation to Feeding

After birth the gastrointestinal tract is colonized by several bacterial species: Esch. coli, Clostridium welchii, streptococci, bacteroides, and lactobacilli. This colonization seems to proceed according to a uniform schedule in different mammals, including man (Smith and Crabb, 1961), which has been ascribed to the fact that young animals of different species are all fed with milk.

In 1905 Tissier found that anaerobic Bacterium bifidum predominated over coliform bacteria in the faecal flora of breast-fed infants, and that this relation was reversed by bottle feeding. The Esch. coli counts never reach as high as $10^{10}$ organisms $/ \mathrm{g}$ faeces in breast-fed infants, whereas in the bottle fed they commonly do so (Bullen and Willis, 1971). In addition, faeces from bottle-fed infants grow proteus and Pseudomonas aeruginosa (Bullen and Willis, 1971). Whether Clostridium welchii and bacteroides appear in the faeces of breast-fed infants is controversial (Smith and Crabb, 1961; Bullen and Willis, 1971). Bacteria of the Klebsiella cloacae group have been reported to be frequent gastrointestinal colonizers of the neonates in some maternity wards (Gareau et al., 1959).

The throats of breast-fed babies are reported to be less often colonized with Esch. coli than those partly or entirely bottle fed, and Esch. coli contamination of the artificial food seemed not to account for this (McFarlan, Crone, and Tee, 1949).

It is so far unknown whether the common colonization of the newborn with Candida albicans is related to bottle feeding or not. It has been shown that unsaturated lactoferrin of breast milk inhibits growth of Candida albicans (Kirkpatrick et al., 1971).

\section{Infections in the Newborn in Relation to Feeding}

The difference in incidence of enteric infections in breast-fed and in bottle-fed infants is well known. It is hard to judge whether this difference is due to a beneficial effect of breast milk or an increased contamination during bottle feeding. A protective role of breast milk against enteric infections is suggested, however, from several observations. An epidemic among newborns of enterocolitis caused by Esch. coli O 111-B4 remained uncontrolled for 6 months in spite of the use of classical epidemiological measures: administration of unprocessed breast milk to all the newborns was accompanied by a rapid cessation of the epidemic (Tassovatz and Kotsitch, 1961). Svirsky-Gross 
(1958) showed a rapid improvement of diarrhoea caused by Esch. coli $\mathrm{O} 111$ after feeding breast milk. Crosse (1966) states that she has never observed an enteropathogenic Esch. coli (EPEC) infection in a breast-fed newborn. In a recent study among newborns and small infants of a preindustrial society in Guatemala, Mata and Urrutia (1971) showed that diarrhoea was uncommon in breast-fed infants though exposure to shigella, enteropathogenic Esch. coli, and salmonella was common. Diarrhoea appeared with weaning.

More difficult to evaluate with regard to a beneficial effect of breast milk-though often citedare studies of neonatal shigella infections, showing a low incidence of neonatal shigellosis in countries with endemic shigella infection. Neonatal shigella infection in such environments is said to be very mild (Mata et al., 1969; Floyd, Higgins, and Kader, 1956), whereas in the western part of the world shigella infections are followed by severe symptoms (Haltalin, 1967; Salzman, Sher, and Moss, 1967) and sometimes septicaemia (Whitfield and Humphries, 1967). Different habits with regard to breast feeding may account for these reported differences. A similar difference between industrialized and nonindustrialized societies with regard to enteropathogenic Esch. coli was pointed out by Mata and Urrutia (1971).

Breast milk feeding interferes with oral poliovaccination (Warren et al., 1964). It has been suggested that breast-fed infants are less prone to respiratory infections and otitis media (Robinson, 1951; von Sydow and Faxén, 1954; Mellander, Vahlqvist, and Mellbin, 1959), though evaluation of such data is difficult (Stanfield, 1959). Finally, some indirect evidence suggests that breast milk may protect against septicaemia and meningitis in the newborn (Winberg and Wessner, 1971).

Components and Properties of Breast Milk Which May Provide Its Protective Properties

Immunoglobulins. Breast milk contains immunoglobulins with antibody activity against several micro-organisms (Hanson and Johansson, 1970). Hitherto these antibodies have been supposed to be of minor importance since they are not absorbed by the gut of the human infant (Vahlquist, 1953; Ammann and Stiehm, 1966), but this assumption became questioned when it was discovered that IgA was the predominant immunoglobulin in milk in contrast to serum (Gugler et al., 1958; Hanson, 1960, 1961) and that the milk IgA was antigenically different from serum IgA (Hanson, 1961). Milk IgA forms part of a local defence system consisting of locally produced 'secretory
IgA' making up the dominating immunoglobulin in most secretions (Tomasi et al., 1965). It has been suggested that this secretory immunoglobulin effects an antimicrobial protection of mucous membranes (Tomasi and Bienenstock, 1968). These facts make it likely that the function of milk antibodies will be locally acting, primarily in the gastrointestinal tract (Hanson and Brandtzaeg, 1972; Gindrat et al., 1972).

Breast milk contains antibodies against the most important bacterial pathogen of the neonate, Esch. coli (Kenny, Boesman, and Michaels, 1967; Michael, Ringenback, and Hottenstein, 1971; Gindrat et al., 1972). Recently it was noted that such milk antibodies are directed against Esch. coli of those $\mathrm{O}$ groups which are commonly found to be causing neonatal infections (Gindrat et al., 1972). This finding may be relevant to the observation that in a group of neonates with Esch. coli septicaemia or meningitis, the breast milk consumption was lower than in controls (Winberg and Wessner, 1971). This observation may be a parallel to that of several authors (e.g. Warren et al., 1964) that breast milk containing polio-antibody prevents successful oral immunization with live polio virus vaccine by neutralizing the virus in the gut.

The Esch. coli antibodies in human milk primarily seem to be of the secretory IgA class (Hodes et al., 1964; Hanson and Johansson, 1970), though small amounts of IgG and IgM are also found in milk (Hanson and Johansson, 1970). Antibody activity against other micro-organisms like polio virus, streptococci, and pneumococci has also been shown in the secretory IgA fraction of human milk (Hodes et al., 1964; Hanson and Johansson, 1970; Mouton et al., 1970).

The secretory IgA molecule is more resistant to $p \mathrm{H}$ changes and proteolytic enzymes than is serum IgA or other immunoglobulins (Tomasi and Bienenstock, 1968; Hanson and Brandtzaeg, 1972), which may enable the secretory $\operatorname{IgA}$ antibodies of milk to function in the variable milieu of the gut. Some preliminary experiments have indicated, however, that a nucleotide dependent reductase isolated from liver can split secretory IgA (Hanson et al., 1972). Similar enzymes are produced by microorganisms such as Esch. coli present in the gut (Moore, Reichard, and Thelander, 1964), so it may be that such enzymes are able to attack the secretory IgA antibodies of milk.

In early colostrum as much as 20 to $40 \mathrm{mg} / \mathrm{ml}$ of IgA may be found (Amman and Stiehm, 1966; Hanson et al., 1971). After the first 2 to 4 days there is a drop to values at the level of $1 \mathrm{mg} / \mathrm{ml}$, but the increase in milk production may then 
compensate for the fall in immunoglobulin concentration. (An analogous situation was described by Schubert and Grünberg in a study of typhoid agglutinins (1949).) The infant ingests sufficient amounts of these milk antibodies, mainly consisting of the stable secretory IgA, to permit their detection in the stools (Kenny et al., 1967; Michael et al., 1971; Gindrat et al., 1972), where a correlation between the titres of such coproantibodies and a reduction in the number of coliform bacteria in the stool could be shown (Michael et al., 1971).

Cellular, enzymic, and protein components of breast milk. The antimicrobial activity of breast milk is not only mediated by antibodies. Milk also contains lymphoid cells which produce IgA and mediate cellular immunity, as well as neutrophils and macrophages with phagocytic activity (Smith and Goldman, 1968; Murillo and Goldman, 1970). As many as 1000 to 4000 leucocytes $/ \mathrm{mm}^{3}$ are regularly found in breast milk during the first 2 weeks after delivery (Mohr, Leu, and Mabry, 1970). These cells may play a part in preventing infection in the maternal gland as well as in the infant's gastrointestinal tract.

Lysozyme (muramidase), which has antibacterial activity, is found in breast milk in amounts up to about $2 \mathrm{mg} / \mathrm{ml}$ (Hanson and Johansson, 1970); its possible influence on the faecal flora is suggested by the fact that it is found in significant amounts in the stools of breast-fed infants.

Human milk also contains large quantities of an iron-binding protein, lactoferrin, which is structurally different from transferrin (Hanson and Johansson, 1970). Lactoferrin has a strong bacteriostatic effect on Esch. coli, as elegantly shown recently by Bullen, Rogers, and Leigh (1972). Its bacteriostatic effect was potentiated by coli antibodies, but was abolished by saturation with iron, raising the important possibility that iron therapy may interfere with the function of lactoferrin. Cow's milk formulae contain much less lysozyme and lactoferrin than human milk.

A resistance factor against staphylococci is present in human milk (György, 1971) and seems to consist of a fatty acid. Its protective role has only been shown in mice so far.

Chemical components of breast milk. The striking influence of breast milk on the faecal flora, with the suppression of Esch. coli and other Gram-negatives and promotion of such organisms as lactobacilli, may still not be mainly due to such factors as antibodies, lysozyme, and lactoferrin listed above, for the high lactose, low protein, and low phosphate content, together with the poor buffering capacity of breast milk may yet prove to be of equal or greater importance (Bullen and Willis, 1971). In addition there is the bifidus factor belonging to a group of nitrogen-containing carbohydrates which promotes the growth of Lactobacillus bifidus, and this factor is more readily to be found in human than in cow's milk (György, 1971).

In summary, human milk contains many components which may both promote a 'normal' bacterial colonization of the gastrointestinal tract, and also suppress the invasiveness of certain pathogenic micro-organisms. These qualities of breast milk may be of major importance for the newborn infant's defence against infection, but further studies are needed to support this view.

\section{A. HANSON and J. WINBERG Department of Immunology, Institute of Medical Microbiology, University of Göteborg, Göteborg, and Department of Pediatrics, University of Umeå, Sweden.}

\section{REFERENCES}

Ammann, A. J., and Stiehm, E. R. (1966). Immuno globulin levels in colostrum and breast milk, and serum from formulaand breast-fed newborns. Proceedings of the Society for Experimental Biology and Medicine, 122, 1098.

British Medical fournal (1970). Editorial. Infection in the nursery, 3, 235.

Bullen, C. L., and Willis, A. T. (1971). Resistance of the breastfed infant to gastroenteritis. British Medical fournal, 3, 338.

Bullen, J. J., Rogers, H. J., and Leigh, L. (1972). Iron-binding protein in milk and resistance to Escherichia coli infection in infants. British Medical fournal, 1, 69.

Conn, N. K. (1969). Coliform bacteraemia in infants. Scottish Medical fournal, 14, 23.

Crosse, V. M. (1966). The Premature Baby, p. 143. Churchill, London.

Floyd, T. M., Higgins, A. R., and Kader, M. A. (1956). Studies in shigellosis. V. The relationship of age to the incidence of Shigella infections in Egyptian children, with special reference to shigellosis in the newborn and in infants in the first six months of life. American fournal of Tropical Medicine and Hygiene, 5, 119.

Gareau, F. E., Mackel, D. C., Boring, J. R., Payne, F. J., and Hammett, F. L. (1959). The acquisition of fecal flora by infants from their mothers during birth. Fournal of Pediatrics, 54, 313.

Gindrat, J.-J., Gothefors, L., Hanson, L. A., and Winberg, J. (1972). Antibodies in human milk against $E$. coli of the serogroups most commonly found in neonatal infections. Acta Paediatrica Scandinavica, 61, 587.

Gugler, E., Bokelmann, G., Dätwyler, A., and von Muralt, G. (1958). Ueber immunoelectrophoretische Untersuchungen an Frauenmilchproteinen. Schweizerische Medizinische Wochenschrift, 88, 1264.

György, P. (1971). The uniqueness of human milk, biochemical aspects. American fournal of Clinical Nutrition, 24, 970.

Haltalin, K. C. (1967). Neonatal shigellosis: report of 16 cases and review of the literature. American fournal of Diseases of Children, 114, 603.

Hanson, L. $\AA$. (1960). The serological relationship between human milk and blood plasma. International Archives of Allergy and Applied Immunology, 17, 45. 
Hanson, L. A. (1961). Comparative immunological studies of the immune globulins of human milk and of blood serum. International Archives of Allergy and Applied Immunology, 18, 241.

Hanson, L. A., Borssén, R., Holmgren, J., Jodal, U., Johansson, B. G., and Kaijser, B. (1971). Secretory IgA. In Immunologic Incompetence. Ed. by B. M. Kagan and E. R. Stiehm. Year Book Medical Publishers, Chicago.

Hanson, L. A., and Brandtzaeg, P. (1972). Secretory antibody systems. In Immunologic Disorders in Infants and Children. Ed. by E. R. Stiehm and V. A. Fulginiti. Saunders, Philadelphia. (In the press.)

Hanson, L. A., and Johansson, B. G. (1970). Immunological studies of milk. In Milk Proteins; Chemistry and Molecular Biology, Vol. I. Ed. by H. A. McKenzie. Academic Press, New York.

Hanson, L. Å., Motas, C., Barrett, J., and Jodal, U. (1972). Studies on the main immunoglobulin of human milk: secretory IgA. Proceedings of the Second International Symposium on the Immunology of Reproduction. (In the press.)

Hodes, H. L., Berger, R., Ainbender, E., Hevizy, M. M., Zepp, H. D., and Kochwa, S. (1964). Proof that colostrum polio antihody is different from serum antibody. (Abst.) fournal of Pediatrics, 65, 1017.

Kenny, J. F., Boesman, M. I., and Michaels, R. H. (1967). Bacterial and viral coproantibodies in breast-fed infants. Pediatrics, 39, 202.

Kirkpatrick, C. H.. Green, I., Rich, R. R., and Schade, A. L. (1971). Inhibition of growth of Candida albicans by iron-unsaturated lactoferrin: relation to host defense mechanisms in chronic mucocutaneous candidiasis. Fournal of Infectious Diseases, 124, 539.

McCracken, G. H., and Shinefield, H. R. (1966). Changes in the pattern of neonatal septicemia and meningitis. American fournal of Diseases of Children, 112, 33.

McFarlan, A. M., Crone, P. B., and Tee, G. H. (1949). Variations in bacteriology of throat and rectum of infants in two maternity units. British Medical fournal, 2, 1140.

Mata, L. J., and Urrutia, J. J. (1971). Intestinal colonization of breast-fed children in a rural area of low socioeconomic level. Annals of the New York Academy of Sciences, 176, 93.

Mata, L. J., Urrutia, J. J., Garcia, B., Fernández, R., and Béhar, M. (1969). Shigella infection in breast-fed Guatemalan Indian neonates. American fournal of Diseases of Children, 117, 142.

Mellander, O., Vahlqvist, B., and Mellbin, T. (1959). Breast feeding and artificial feeding. The Norrbotten study. Acta Paediatrica 48, Suppl. 116, 1.

Michael, J. G., Ringenback, R., and Hottenstein, S. (1971). The antimicrobial activity of human colostral antibody in the newborn. Fournal of Infectious Diseases, 124, 445.

Mohr, J. A., Leu, R., and Mabry, W. (1970). Colostral leucocytes. fournal of Surgical Oncology, 2, 163.

Moore, E. C., Reichard, P., and Thelander, L. (1964). Enzymatic synthesis of deoxyribonucleotides, I. Purification and properties of thioredoxin reductase from Escherichia coli $B$. Fournal of Biological Chemistry, 239, 3445.
Mouton, R. P., Stoop, J. W., Ballieux, R. E., and Mul, N. A. J. (1970). Pneumococcal antibodies in IgA of serum and external secretions. Clinical and Experimental Immunology, 7, 201.

Murillo, G. J., and Goldman, A. S. (1970). The cells of human colostrum. II. Synthesis of IgA and $\beta_{1 \mathrm{c}}$. Pediatric Research, 4, 71

Robinson, M. (1951). Infant morbidity and mortality, a study of 3266 infants. Lancet, $1,788$.

Salzman, T. C., Sher, C. D.. and Moss, R. (1967). Shigellae with transferable drug resistance: outbreak in a nursery for premature infants. Fournal of Pediatrics, 71, 21.

Samuel, M. E., and Gould, J. C. (1967). Bacteriological studies in a nursery during a trial with cephaloridine. Postgraduate Medical fournal, 43, Suppl. on cephaloridine, 109.

Schubert, J., and Grünberg, A. (1949). Zur Frage der Uebertragung von Immun-Antikörpern von der Mutter auf das Kind. Schweizerische Medizinische Wochenschrift, 79, 1007.

Smith, C. W., and Goldman, A. S. (1968). The cells of human colostrum. I. In vitro studies of morphology and functions. Pediatric Research, 2, 103.

Smith, H. W., and Crabb, W. E. (1961). The faecal bacterial flora of animals and man: its development in the young. fournal of Pathology and Bacteriology, 82, 53.

Stanfield, P. (1959). Breast feeding and artificial feeding-a survey of the literature. Acta Paediatrica 48, Suppl. 116, 11.

Svirsky-Gross, S. (1958). Pathogenic strains of coli (0, 111) among prematures and the use of human milk in controlling the outbreak of diarrhea. Annales Paediatrici, 190, 109.

von Sydow, G., and Faxén, N. (1954). Breast or cow's milk as infant food. Discussion on the methods of comparison. Acta Paediatrica, 43, 362.

Tassovatz, B., and Kotsitch, A. (1961). Le lait de femme et son action de protection contre les infections intestinales chez le nouveauné. Annales de Pédiatrie, 8, 285.

Tissier, H. (1905). Répartition des microbes dans l'intestin du nourisson. Annales de l'Institut de Pasteur, 19, 109.

Tomasi, T. B., Jr., and Bienenstock, J. (1968). Secretory immunoglobulins. In Advances in Immunology, Vol. 9. Ed. by F. J Dixon and H. G. Kunkel. Academic Press, New York and London.

Tomasi, T. B., Tan, E. M., Solomon, A., and Prendergast, R. A. (1965). Characteristics of an immune system common to certain external secretions. Fournal of Experimental Medicine, 121, 101

Vahlquist, B. (1958). The transfer of antibodies from mother to offspring. In Advances in Pediatrics, Vol, 10, p. 305 . Ed. by S. Z. Levine. Year Book Medical Publishers, Chicago.

Warren, R. J., Lepow, M. L., Bartsch, G. E.. and Robbins, F. C. (1964). The relationship of maternal antibody, breastfeeding, and age to the susceptibility of newborn infants to infection with attenuated polioviruses. Pediatrics, 34, 4.

Whitfield, C., and Humphries, J. M. (1967). Meningitis and septicemia due to Shigellae in a newborn infant. fournal of Pediatrics, 70, 805.

Winberg, J., and Wessner, G. (1971). Does breast milk protect against septicemia in the newborn? Lancet, 1, 1091. 